\title{
Changes in texture and liquid holding capacity of spiced Liquid Smoked Silver carp (Hypophthalmichthys molitrix) muscle wrapped in Aluminium Foil during refrigerated storage
}

\author{
Frank Fijelu, Wenshui Xia* \\ School of Food Science and Technology, Jiangnan University, Wuxi, Jiangsu 214122, China \\ Email address: \\ frankfijelu@rocketmail.com (Frank Fijelu),xiaws@jiangnan.edu.cn (Wenshui Xia)
}

To cite this article:

Frank Fijelu, Wenshui Xia. Changes in Texture and Liquid Holding Capacity of Spiced Liquid Smoked Silver Carp (Hypophthalmichthys Molitrix) Muscle Wrapped in Aluminium Foil during Refrigerated Storage. International Journal of Nutrition and Food Sciences.

Vol. 3, No. 2, 2014, pp. 19-25. doi: 10.11648/j.ijnfs.20140302.12

\begin{abstract}
The effects of equivalent concentrations of both garlic and ginger separately in fresh and powder form in muscle proteins of liquid smoked silver carp (Hypophthalmichthys molitrix) during chilled storage were investigated for a period of 24 days. The control and the treated smoked fish samples were analysed periodically for liquid holding capacity, salt extractable protein, texture and sensory quality characteristics. The results showed loss of that liquid holding capacity, salt extractable protein content for all sample $(\mathrm{P}<0.05)$, however more loss observed on ginger treated samples. Force required compressing or shearing the sample as hardness, decreased more in ginger incorporated samples $(p<0.05)$. Sensory parameters of odour, texture, and appearance for all samples decreased during the chilled storage period $(p<0.05)$ but were still within acceptable limits, except on texture of fresh ginger samples at day 24 . The results obtained from this study suggest that ginger in fresh and powder form, have high negative impacts on texture properties and protein functionality of liquid smoked silver carp muscle stored at $4 \pm 1{ }^{\circ} \mathrm{C}$.
\end{abstract}

Keywords: Proteolytic Activity, Silver Carp, Liquid Smoke, Biopreservation

\section{Introduction}

Silver carp (Hypophthalmichthys molitrix), a main farmed freshwater fish species and increasingly aquacultured worldwide, has attracted much attention in recent years owing to its fast growth rate, low feed demand and resistance to diseases[31], high quality nutritious protein $(15-18 \%, \mathrm{w} / \mathrm{w})$, excellent white color and low market price [12]. However, silver carp are perishable foods, which generally spoil faster than do other muscle foods. Spices, application has proven to be an effective preservation method for the extension of shelf life of fish, due to its natural antimicrobial and antioxidant properties $[4,11]$. It is known that, some of spices have been also shown to have a powerful proteolytic activity; hence affects texture properties and protein functionality $[6,26,28]$.

The texture of fish is an important quality characteristic, it determines consumer acceptance and hence the marketability of the final products [18], however, texture related problems, such as muscle softening and gaping, are frequently observed, due to the very delicate nature of fish muscle [13]. Firmness is an important aspect of fish quality as opposed to tenderness which is appreciated in meat consumption [9]. There is some evidence that in fish a relationship exists between harvest procedures and aspects of quality such as liquid holding capacity or texture. Little work has been focused on rheological properties of smoked fillets particularly on liquid-holding capacity [15].

Lipid and water together make up about $80 \%$ of fish muscle. Depending on the properties of the flesh and how it is treated, it may gain or lose water. This is important economically since fish is sold by weight. The content of water and its distribution within the flesh also affects the quality [19]. The 'free' water, amounts to about $90 \%$ of the tissue water, is held by capillary and surface tension forces mainly in intracellular locations. Water holding capacity of muscle is greatly influenced by structural changes in the muscle proteins, fibril swelling-contraction and the 
distribution of fluid between intra and extracellular locations [29]. Liquid losses during and after smoking have caused problems for the fish processing industry. When these liquid losses are apparent in the consumer packages, it is not acceptable for the producer, and even worse for the final customer [30].

The objectives of this study were to investigate the texture and liquid holding capacity behavior in muscle proteins of liquid smoked silver carp muscle treated with equivalent concentrations of two garlic and ginger preparations, (fresh and powder form) wrapped in aluminum foil during refrigerated storage.

\section{Materials and Methods}

\subsection{Materials}

Fresh garlic bulbs (Allium sativum, Chinese white garlic) and Fresh ginger (Zingiber officinale, Chinese yellow ginger) were purchased from a local market. The dry skins of both fresh garlic and ginger were removed before use; then were peeled and crushed finely by using a kitchen hand held grater. Garlic powder and ginger powder were purchased from a supermarket. $4 \mathrm{~kg}$ of produced garlic powder is weight equivalent to $16 \mathrm{~kg}$ of fresh garlic; also $2 \mathrm{~kg}$ of produced ginger powder is the weight equivalents of $10 \mathrm{~kg}$ of fresh ginger, according to the manufacturer details.

\subsection{Preparation of Fish}

Silver carp (Hypophthalmichthys molitrix) with average weight of $815.12 \pm 14.55 \mathrm{~g}$ were purchased from a local market (Wuxi, Jiangsu, China), transported within 1hour in sealed polystyrene foam boxes containing ice to the Food Processing Technology Laboratory at Jiangnan University, where processing were carried out, then randomly divided into 5 groups for further treatments after gutted, eviscerated, deboned, removed the scale, skin, pin bones, debris, and filleted.

\subsubsection{Sample Treatment and Brining with Liquid Smoke}

$\mathrm{C}$ : The samples without ginger and garlic treatment

$\mathrm{T} 1: 10 \mathrm{~g} / \mathrm{Kg}$ ginger powder was added on brine.

$\mathrm{T} 2: 50 \mathrm{~g} / \mathrm{Kg}$ of fresh ginger applied on fish for 4hours at $4 \pm 1{ }^{\circ} \mathrm{C}$ after brining.

T3: $12.5 \mathrm{~g} / \mathrm{Kg}$ garlic powder was added on brine.

$\mathrm{T} 4: 50 \mathrm{~g} / \mathrm{Kg}$ of fresh garlic applied on fish for 4hours at $4 \pm 1{ }^{\circ} \mathrm{C}$ after brining.

All samples above were immersed in brine containing $10 \%$ sodium chloride and $1 \%$ of commercial liquid-smoked flavoring at a ratio of $1: 1(\mathrm{w} / \mathrm{w})$ for 4 hours at $4 \pm 1{ }^{\circ} \mathrm{C}$.

\subsubsection{Drying and Cooling of Samples}

All samples were dried in a thermo ventilated oven at $75^{\circ} \mathrm{C}$ for 80 minutes. After cooling at $20^{\circ} \mathrm{C}$ for 30 minutes, the smoked products were, wrapped in aluminium foil, and stored at $4 \pm 1{ }^{\circ} \mathrm{C}$ until analysis which performed in replicates on day $0,6,12,18$ and 24 of storage.

\subsection{Proximate Analysis}

A proximate composition analysis was performed on five fish samples on day 0 of preservation. Moisture content was measured using a gravimetric method by drying the sample in an air oven at $105^{\circ} \mathrm{C}$ until it reached constant weight [1]. Crude protein content was calculated by converting the nitrogen content determined by Kjeldahl's method $(6.25 \times N)$. Fat was determined by the method described by the [7]. Ash was determined from the residue after burning in a muffle furnace at $525^{\circ} \mathrm{C}$ for around $18 \mathrm{~h}$ [1].

\subsection{Determination of Salt Extractable Proteins (SEP)}

To extract SEP, $2 \mathrm{~g}$ fish fillet was washed with $10 \mathrm{~mL}$ phosphate buffer $[\mathrm{I}=0.05, \mathrm{pH} 7.5]$ twice, then centrifuged for $5 \mathrm{~min}$ at $10,000 \mathrm{r} / \mathrm{min}$ and $4^{\circ} \mathrm{C}$ to remove the buffer, and homogenized with $30 \mathrm{~mL}$ chilled $\left(4^{\circ} \mathrm{C}\right) 0.6 \mathrm{M} \mathrm{KCl}$ for $1 \mathrm{~min}$ using a homogenizer (FW 2000, Fluko Co. Ltd, Shanghai, China), then the sample was placed in the fridge at $4{ }^{\circ} \mathrm{C}$ for $1 \mathrm{~h}$. The extract was centrifuged for $30 \mathrm{~min}$ at $10,000 \mathrm{r} / \mathrm{min}$ and $4{ }^{\circ} \mathrm{C}$ using a centrifuge (TGL-16A, Pingfan Instrument and Meter Co. Ltd, Changsha, China), and the concentration of salt extractable proteins was determined by biuret method using bovine serum albumin as a standard (Robinson and Hodgen,1940). $\mathrm{KCl}$ solution (0.6M) was used as blank. SEP was expressed as the ratio of protein content in the supernant to the mass of fillet, $\mathrm{mg} / \mathrm{ml}$.

\subsection{Liquid Holding Capacity}

The LHC was determined using the method described by [24]. Duplicate fillet samples (15 g) were weighed and placed in a tube with a weighted filter paper (V1) (Scheilcher \& Schuell GmbH, Dassel, Germany). The tubes were centrifuged at $500 \mathrm{xg}$ for $10 \mathrm{~min}$ at $10^{\circ} \mathrm{C}$, and the wet paper was weighted (V 2) before drying at $50^{\circ} \mathrm{C}$ to constant weight (V3). The liquid loss as \% was calculated as $100 \mathrm{x}$ (V1-V 2) $\mathrm{xS}^{-1}$, where $\mathrm{S}=$ weight of fillet sample, water loss as $100 \times(\mathrm{V} 2-\mathrm{V} 3) \mathrm{x} \mathrm{S}^{-1}$ and fat loss as $100 \times(\mathrm{V} 3-\mathrm{V} 1) \times \mathrm{S}^{-}$ ${ }^{1}$. All losses were expressed as percentage of muscle wet weight.

\subsection{Texture Profile Analysis (TPA)}

Instrumental texture analyses were performed using a Texture Analyser TA-XT2 (SMS Ltd., Surrey, England) equipped with a $5 \mathrm{~kg}$ load cell. The probe was a flat-ended cylinder (12.5 mm diameter, type $\mathrm{P} / 0.5$ ). The force required to penetrating the cylinder through the fillet surface was registered.

\subsection{Determining Sensory Quality}

The sensory quality of liquid smoked silver carp was evaluated by 7 trained and selected assessors. Two smoked fillets per treatment were analysed in every session. Samples were cut in ca. fifty-gram pieces for every panelist and presented in plastic cups covered with a lid in random 
order. The evaluation took place in separate booths under daylight illumination. The assessors were asked to evaluate the appearance, the freshness of the odour and the texture of the samples. A quality scale from 0 to 10 was used. A score of 10 was defined as excellent a score $\leq 4$ was defined as very poor and unfit for human consumption and 0 was defined as Very bad. Sensory evaluations were performed at each sampling time (day $0,6,12,18,24$ ).

\subsection{Statistical Analysis}

For data analysis, analysis of variance (ANOVA) was used. Significant differences were defined at $(\mathrm{P}<$ 0.05).Comparisons of group means were obtained using Duncan's multiple range tests. All statistical analysis was performed using SPSS version 19.0 for windows software (SPSS Inc., Chicago, IL).

\section{Results and Discussion}

\subsection{Proximate Composition}

The proximate composition of liquid smoked silver carp fillets determined in the initial fish samples before being treated with preservatives. The moisture, crude protein, lipid and crude ash contents produced from fish fillet were found to be $740.3 \mathrm{~g} \mathrm{~kg}^{-1}, 179.8 \mathrm{~g} \mathrm{~kg}^{-1}, 57.5 \mathrm{~g} \mathrm{~kg}^{-1}$ and 12.8 $\mathrm{g} \mathrm{kg}^{-1}$, respectively. The proximate composition of silver carp reported in different studies [17, 33] indicated some differences, especially for the lipid content and protein. Such differences in the composition of fish are strongly related to their nutrition, catching season (spawning cycles), environment, fish size and gender [23]. The compositional variations may lead to the changes in sensory attributes, and also can affect the microbial growth.

\subsection{Salt Extractable Protein}

The changes in the SEP content as an indicator of protein denaturation were presented in Fig. 1. It was found that SEP content of the frozen fish samples decreased significantly with increasing storage time $(P<0.05)$, similar trend was also observed in other fish muscle systems when spices are not incorporated [27, 38]. The SEP content of $6.79,6.32,6.02,5.04$ and $4.85 \mathrm{mgml}^{-1}$ for $\mathrm{T} 4, \mathrm{~T} 3, \mathrm{C}, \mathrm{T} 1$ and $\mathrm{T} 2$ respectively were observed, and having been decreased to, after 24 day of frozen storage, $41.53,30.54,24.25,20.24$ and $14.84 \%$ of its initial SEP values, respectively. However, after day 6 of storage, the SEP content in garlic treated (T4 andT3) samples were significantly $(P<0.05)$ higher than in the $\mathrm{C}, \mathrm{T} 1$ and $\mathrm{T} 2$ samples. From the SEP results, noted that addition of ginger in a samples resulted to largest SEP loss throughout the storage time, compared to control samples, this result indicated that the higher protein denaturation and damage associated with the proteolytic activity of ginger incorporated $[2,20]$.The antioxidant efficiency of garlic is due to rich in organsulfur compounds and their precursors (allicin, diallyl sulfide and diallyl trisulfide) have biological actions to retard lipid oxidation [14, 22, 37], resulted to lowest SEP loss throughout the storage time for garlic incorporated samples, compared to control and ginger treated samples, since interaction between protein and lipid oxidation products, causing a decline of protein solubility $[3,34]$. The decrease in SEP for control samples during frozen storage could be resulted from the formation of hydrogen or hydrophobic bonds, as well as disulfide bonds and ionic interactions $[5,32,36]$.

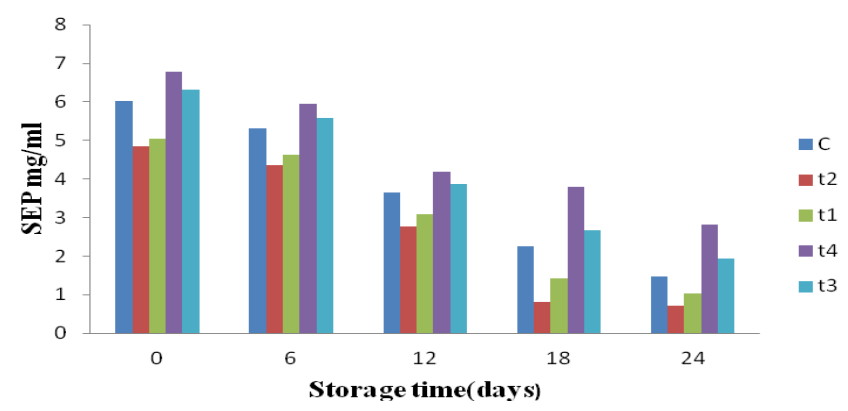

Figure 1. The changes in the salt extractable protein content of smoked silver carp during storage

\subsection{Liquid Holding Capacity}

It is well known that determination of LHC in meat and fish is important for economical reasons (weight decrease due to water loss) and for sensor y properties (colour, juiciness and tenderness; [30]. LHC of smoked fillets was significantly affected by addition of garlic and ginger (Table 1a, b, c). At $(P<0.05)$ liquid loss from smoked fish fillet for garlic incorporated smoked fillets was significantly lower than loss from smoked fish treated with control and ginger incorporated smoked fillets. Water loss of smoked fillets was low but significantly different between treatments. Fat loss from fish smoked fish treated with control and ginger incorporated smoked fillets were higher than those of garlic incorporated smoked fillets. Our results, therefore, indicate that addition of ginger to smoked fish could cause low liquid holding capacity, since ginger proteases could extensively degrade several major cytoskeletal/myofibrillar proteins (titin, MHC, troponin-T, desmin and $\alpha$-actinin), which could lead to the breakdown of the integrity of muscle structure [35], while lowest LHC for control samples contributed by several parameters, such as ionic strength, $\mathrm{pH}$, temperature, detachment of sarcolemma, gaps in the extracellular matrix, widening of the intermyofibrillar space, and transversal shrinkage of the muscle fibres. Moreover, given that the majority of the water in the flesh is bound to the myofibrils, and that muscle LHC is linked to myofibrils spacing, cathepsins proteases having a significant impact on the protein content could potentially affect the LHC of the muscle [26]. 
Table 1. a, b, c Liquid holding capacity measurements

\begin{tabular}{|c|c|c|c|c|c|}
\hline \multirow{2}{*}{$\begin{array}{l}\text { Parameter/ } \\
\text { Treatment }\end{array}$} & \multicolumn{5}{|c|}{ Storage period(days) } \\
\hline & $\mathbf{0}$ & 6 & 12 & 18 & 24 \\
\hline Liquid Loss (\%) & & & & & \\
\hline Control & $12.00 \pm 0.14^{\mathrm{aC}}$ & $13.00 \pm 0.42^{\mathrm{baB}}$ & $16.00 \pm 2.80^{\mathrm{cbBA}}$ & $18.3 \pm 0.42^{\mathrm{dcB}}$ & $21.8 \pm 1.13^{\mathrm{dB}}$ \\
\hline $\mathrm{T} 1$ & $13.00 \pm 0.88^{\mathrm{aD}}$ & $14.70 \pm 0.75^{\mathrm{abC}}$ & $16.80 \pm 0.58^{\mathrm{bBA}}$ & $21.00 \pm 0.10^{\mathrm{cC}}$ & $22.00 \pm 0.31^{\mathrm{cB}}$ \\
\hline $\mathrm{T} 2$ & $18.00 \pm 0.11^{\mathrm{aE}}$ & $18.67 \pm 0.52^{\mathrm{aD}}$ & $19.00 \pm 0.75^{\mathrm{aB}}$ & $22.30 \pm 0.13^{\mathrm{bBC}}$ & $24.70 \pm 0.45^{\mathrm{cC}}$ \\
\hline $\mathrm{T} 3$ & $8.30 \pm 0.06^{\mathrm{AA}}$ & $13.00 \pm 0.95^{\mathrm{bB}}$ & $13.00 \pm 0.52^{\mathrm{bA}}$ & $13.30 \pm 0.57^{\mathrm{bA}}$ & $13.50 \pm 0.35^{\mathrm{bA}}$ \\
\hline $\mathrm{T} 4$ & $9.60 \pm 1.21^{\mathrm{aB}}$ & $11.30 \pm 0.82^{\mathrm{bA}}$ & $13.80 \pm 0.13^{\mathrm{cA}}$ & $14.00 \pm 0.14^{\mathrm{cA}}$ & $14.70 \pm 0.23^{\mathrm{cA}}$ \\
\hline \multicolumn{6}{|l|}{ Water Loss (\%) } \\
\hline Control & $10.30 \pm 0.48^{\mathrm{aC}}$ & $11.00 \pm 0.19^{\mathrm{bB}}$ & $14.20 \pm 0.42^{\mathrm{cB}}$ & $16.00 \pm 0.14^{\mathrm{dC}}$ & $19.00 \pm 0.11^{\mathrm{eB}}$ \\
\hline $\mathrm{T} 1$ & $11.4 \pm 0.29^{\mathrm{aD}}$ & $13.1 \pm 0.31^{\mathrm{baC}}$ & $15.00 \pm 0.19^{\mathrm{bCB}}$ & $18.00 \pm 0.32^{\mathrm{cD}}$ & $19.7 \pm 0.34^{\mathrm{cCB}}$ \\
\hline $\mathrm{T} 2$ & $16.00 \pm 0.26^{\mathrm{aE}}$ & $16.30 \pm 0.18^{\mathrm{aD}}$ & $16.90 \pm 0.31^{\mathrm{aC}}$ & $19.30 \pm 0.24^{\mathrm{bE}}$ & $21.00 \pm 0.11^{\mathrm{bC}}$ \\
\hline $\mathrm{T} 3$ & $7.3 \pm 0.32^{\mathrm{aA}}$ & $9.00 \pm 0.41^{\mathrm{bA}}$ & $11.00 \pm 0.13^{\mathrm{cA}}$ & $11.20 \pm 0.15^{\mathrm{dcA}}$ & $12.00 \pm 0.16^{\mathrm{dA}}$ \\
\hline $\mathrm{T} 4$ & $8.80 \pm 0.21^{\mathrm{aB}}$ & $11.00 \pm 0.16^{\mathrm{bB}}$ & $12.00 \pm 0.04^{\mathrm{cbA}}$ & $12.50 \pm 0.14^{\mathrm{cbB}}$ & $13.50 \pm 0.11^{\mathrm{cA}}$ \\
\hline Fat Loss (\%) Control & $1.60 \pm 0.32^{\mathrm{aCB}}$ & $1.69 \pm 0.11^{\mathrm{aBA}}$ & $1.70 \pm 0.23^{\mathrm{aA}}$ & $2.30 \pm 0.14^{\mathrm{bBA}}$ & $2.80 \pm 0.11^{\mathrm{cB}}$ \\
\hline $\mathrm{T} 1$ & $1.70 \pm 0.87^{\mathrm{aC}}$ & $1.86 \pm 0.27^{\mathrm{baB}}$ & $2.00 \pm 0.26^{\mathrm{bA}}$ & $2.60 \pm 0.28^{\mathrm{cCB}}$ & $3.00 \pm 0.11^{\mathrm{dB}}$ \\
\hline $\mathrm{T} 2$ & $2.10 \pm 0.12^{\mathrm{aD}}$ & $2.50 \pm 0.27^{\mathrm{aC}}$ & $3.00 \pm 0.30^{\mathrm{bB}}$ & $3.10 \pm 0.36^{\mathrm{bD}}$ & $4.00 \pm 0.01^{\mathrm{cD}}$ \\
\hline Т3 & $1.30 \pm 1.75^{\mathrm{aBA}}$ & $1.50 \pm 1.23^{\mathrm{aA}}$ & $1.80 \pm 0.24^{\mathrm{bA}}$ & $2.00 \pm 0.16^{\mathrm{bA}}$ & $2.30 \pm 0.21^{\mathrm{cA}}$ \\
\hline $\mathrm{T} 4$ & $1.00 \pm 0.11^{\mathrm{aA}}$ & $1.70 \pm 0.29^{\mathrm{bBA}}$ & $1.80 \pm 0.11^{\mathrm{bA}}$ & $2.10 \pm 0.71^{\mathrm{cDC}}$ & $3.00 \pm 0.37^{\mathrm{cB}}$ \\
\hline
\end{tabular}

${ }^{\mathrm{a}-\mathrm{e}}$ Means with different superscript letters in the same row indicate significant differences $(\mathrm{p}<0.05)$. ${ }^{\mathrm{A}-\mathrm{E}}$ Means with different superscript letters in the same column indicate significant differences $(\mathrm{p}<0.05)$. Data are expressed as means \pm standard deviation $(\mathrm{n}=2)$.

\subsection{Texture Profile Analysis (TPA)}

Texture profile analysis (TPA) was carried out to determinate the effect of spices on the texture of fish muscle during chilled storage. The texture of fish is an important quality characteristic, and soft fillets are a problem for the fish industry [10]. The initial hardness value of silver carp was in the range of 2761.49 to $2850.349 \mathrm{~g}$. The hardness values were significantly $(P<0.05)$ higher in garlic incorporated fillets compared to control and ginger incorporated fillets, however the decrease of hardness values to all samples during storage noted (fig. 2), showing that muscle becomes softer. The highest hardness value for garlic incorporated smoked fillets is may be due ability of garlic to retard the development of peroxide values that is responsible for the increased tenderness. This conclusion was supported by the observation of a negative correlation between peroxide value and tenderness attribute [21,22], while the lowest hardness values for control and ginger incorporated smoked fillets samples during frozen storage could be resulted from, enzymatic degradation that induces many physical mechanisms, among them gaping, which contributes to muscle tenderization. Proteases involved are primarily calpains, cathepsins, and collagenases. Calpains and cathepsins act on the myofibrillar proteins and promote myofibril fragility, and collagenases act on the connective tissue and contribute to gaping [8].

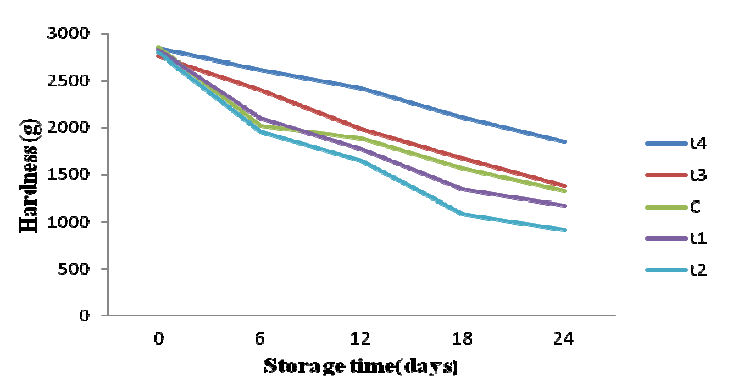

Figure 2. Texture profile analysis of smoked silver carp during storage

\subsection{Sensory Evaluation}

The results of the sensory evaluation of samples are given in fig 3a-c. As the results show the smoked samples were scored as excellent or good throughout the entire storage period except for fresh ginger incorporated samples on texture, scored very poor and unfit for human consumption at day 24 of storage. However all samples showed a similar pattern of decreasing acceptability due to the spoilage patterns described by the panelists were as follows: softening of texture before off-odours developed and presence of bitter and rancid off-flavours, appearance score decreased as colour discolouration increased [11] reported similar trend.

At the start of the storage test there were no significant differences in the odour or in the texture or appearance between the smoking treatments. After 12 days, garlic and ginger treated samples had a significantly higher mean 
odour score than the control samples (Fig. 3a), may be resulted from antioxidant and antimicrobial effects of ginger and garlic, delayed lipid oxidation and microbial growth on smoked fish [16, 39].

After 12 days ginger treated samples had a significantly lower mean texture score than the garlic treated and control samples (Fig. 3b), may be caused by proteolytic activity ginger on collagen was found to be many fold greater than on actomyosin [25]. Garlic treated samples showed the highest degree of appearance after day 12 of storage (fig. $3 \mathrm{c}$ ). The acceptability of the taste of highly spiced food is transmitted both culturally and genetically, and the countries with hotter climates used spices more frequently and at much higher levels than countries with cooler climates [16].

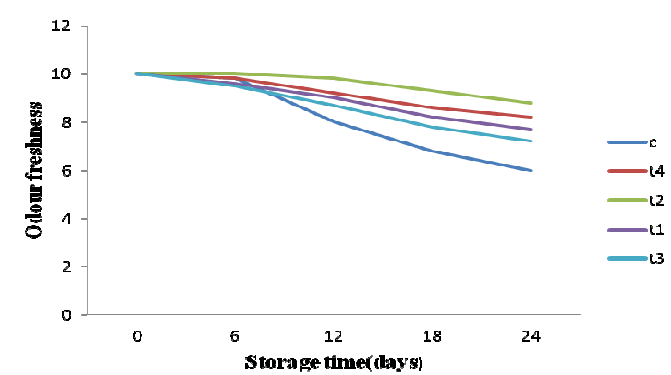

Figure 3a. Odour of freshness of smoked silver carp during storage (Scale from 10 to 0 (10 excellent and 0 very bad). Rejection point 4).

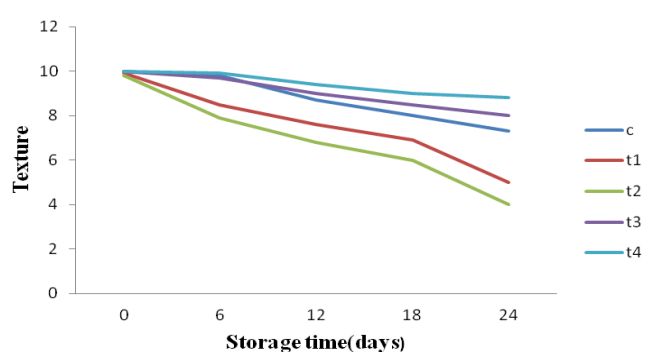

Figure $3 \boldsymbol{b}$. Texture of smoked silver carp during storage (Scale from 10 to 0 (10 excellent and 0 very bad). Rejection point 4).

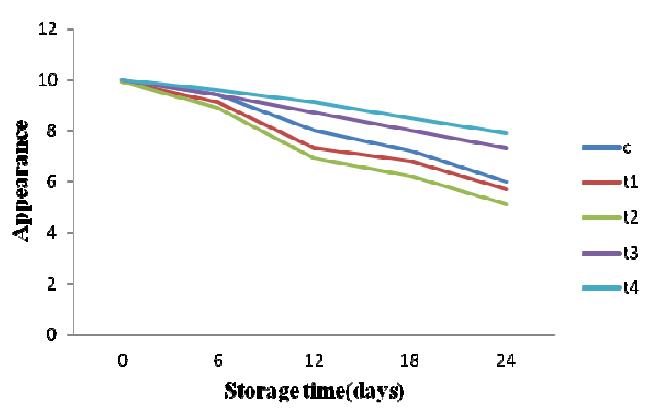

Figure 3c. Appearance of smoked silver carp during storage (Scale from 10 to 0 (10 excellent and 0 very bad). Rejection point 4).

\section{Conclusion}

In general, ginger is usually considered as a spice or seasoning to enhance the aroma in meat products. However, the present study shows that ginger proteases could extensively degrade several major myofibrillar proteins in the ginger incorporated smoked fillets, which could lead to the breakdown of the integrity of muscle structure, hence affects texture properties and protein functionality.

\section{Acknowledgments}

This research was financially supported by the earmarked fund for China Agriculture Research System (CARS-46).

\section{References}

[1] AOAC.(1995). Official Methods of Analyses of Association of Analytical Chemist, 15th edn. Washington, DC: AOAC.

[2] P. Adulyatham and R. Owusu-Apenten, "Stabilization and Partial Purification of a Protease from Ginger Rhizome (Zingiber offinale Roscoe)," Journal of Food Science 70(3),2005, C231-C234.

[3] I. M. Al-Bulushi, S. Kasapis, H. Al-oufi and S. Al-Mamari "Evaluating the quality and storage stability of fish burgers during frozen storage," Fisheries Science 71(3), 2005, 648654 .

[4] M. Attouchi and S. Sadok, "The Effects of Essential Oils Addition on the Quality of Wild and Farmed Sea Bream (Sparus aurata) Stored in Ice." Food and Bioprocess Technology 5(5), 2012, 1803-1816.

[5] S. Benjakul, W. Visessanguan, C. Thongkaew and M. Tanaka, "Effect of frozen storage on chemical and gelforming properties of fish commonly used for surimi production in Thailand." Food Hydrocolloids 19(2), 2005, 197-207.

[6] N. Bhaskar, N. M. Sachindra, V. K. Modi, P. Z. Sakhare and N. S. Mahendrakar, "PREPARATION OF PROTEOLYTIC ACTIVITY RICH GINGER POWDER AND EVALUATION OF ITS TENDERIZING EFFECT ON SPENT-HEN MUSCLES." Journal of Muscle Foods 17(2), 2006, 174-184.

[7] E. G. Bligh and W. J. Dyer, "A RAPID METHOD OF TOTAL LIPID EXTRACTION AND PURIFICATION." Canadian Journal of Biochemistry and Physiology 37(8), 1959, 911-917.

[8] R. Chéret, N. Chapleau, V. Verrez-Bagnis, C. DelbarreLadrat and M. Lamballerie. "Effects of High Pressure on Texture and Microstructure of Sea Bass (Dicentrarchus labrax L.) Fillets." Journal of Food Science 70(8), 2005, e477-e483.

[9] R. Chéret, and C. Delbarre-Ladrat, M. Lamballerie-Anton and V. Verrez-Bagnis, "Calpain and cathepsin activities in post mortem fish and meat muscles." Food Chemistry 101(4), 2007, 1474-1479.

[10] A. S. Duun and T. Rustad, "Quality of superchilled vacuum packed Atlantic salmon (Salmo salar) fillets stored at -1.4 and $-3.6^{\circ} \mathrm{C}$." Food Chemistry 106(1), 2008, 122-131.

[11] N. Erkan, "The Effect of Thyme and Garlic Oil on the Preservation of Vacuum-Packaged Hot Smoked Rainbow Trout (Oncorhynchus mykiss)." Food and Bioprocess Technology 5(4), 2012, 1246-1254. 
[12] X. Fu, S. Xu and Z. Wang, "Kinetics of lipid oxidation and off-odor formation in silver carp mince: The effect of lipoxygenase and hemoglobin." Food Research International 42(1), 2009, 85-90.

[13] H. Godiksen, M. Morzel, G. Hylding and F. Jessen "Contribution of cathepsins B, L and D to muscle protein profiles correlated with texture in rainbow trout (Oncorhynchus mykiss)." Food Chemistry 113(4), 2009, 889-896.

[14] N.Gokoglu and P. Yerlikaya and O. K. Topuz, "EFFECTS OF TOMATO AND GARLIC EXTRACTS ON OXIDATIVE STABILITY IN MARINATED ANCHOVY." Journal of Food Processing and Preservation 36(3), 2012, 191-197.

[15] P. O. Skjervold, S. O. Fjæra, P. B. Ostby and O. Einen, "Live-chilling and crowding stress before slaughter of Atlantic salmon (Salmo salar)." Aquaculture 192(2-4), 2001, 265-280.

[16] K. I. Sallam, M. Ishioroshi and K. Samejima, "Antioxidant and antimicrobial effects of garlic in chicken sausage." LWT - Food Science and Technology 37(8), 2004, 849-855.

[17] Y. Hu, W. Xia and C. Ge,"Characterization of fermented silver carp sausages inoculated with mixed starter culture." LWT - Food Science and Technology 41(4), 2008, 730-738.

[18] L. Hultmann and T. Rustad, "Iced storage of Atlantic salmon (Salmo salar) - effects on endogenous enzymes and their impact on muscle proteins and texture." Food Chemistry 87(1), 2004, 31-41.

[19] R. Ofstad, B. Egelandsdal and S. kidman, "Liquid Loss as Effected by Post mortem Ultrastructural Changes in Fish Muscle: Cod (Gadus morhuaL) and Salmon (Salmo salar)." Journal of the Science of Food and Agriculture 71(3), 1996, 301-312.

[20] M. Kim, S. E. Hamilton, L. W. Guddat and C. M. Overall,"Plant collagenase: Unique collagenolytic activity of cysteine proteases from ginger." Biochimica et Biophysica Acta (BBA) - General Subjects 1770(12), 2007, 1627-1635.

[21] Y. J. Kim, S. K. Jin and I. H. Choi,"THE EFFECT OF GARLIC OR ONION MARINADE ON THE LIPID OXIDATION AND MEAT QUALITY OF PORK DURING COLD STORAGE." Journal of Food Quality 33, 2010, 171185.

[22] Y. J. Kim and B. A. Nahm, et al, "AN EVALUATION OF THE ANTIOXIDANT AND ANTIMICROBIAL EFFECTIVENESS OF DIFFERENT FORMS OF GARLIC AND BHA IN EMULSION-TYPE SAUSAGES DURING REFRIGERATED STORAGE." Journal of Muscle Foods 21(4),2010, 813-825.

[23] T. Li, J. Li, W. Hu, X. Zhang, X. Li and J. Zhao,"Shelf-life extension of crucian carp (Carassius auratus) using natural preservatives during chilled storage." Food Chemistry 135(1), 2012, 140-145.

[24] P, Montero, M. C. GÓMez-GuillÉN and A. J. Borderias, "Influence of Salmon Provenance and Smoking Process on Muscle Functional Characteristics." Journal of Food Science 68(4), 2003, 1155-1160.

[25] B. M. Naveena and S. K. Mendiratta,"THE TENDERIZATION OF BUFFALO MEAT USING
GINGER EXTRACT." Journal of Muscle Foods 15(4), 2004, 235-244.

[26] G. B. Olsson, R. L. Olsen, M. Carlehog and R. Ofstad,"Seasonal variations in chemical and sensory characteristics of farmed and wild Atlantic halibut (Hippoglossus hippoglossus)." Aquaculture 217(1-4), 2003, 191-205.

[27] J. Pan, H. Shen and Y. Luo, "CRYOPROTECTIVE EFFECTS OF TREHALOSE ON GRASS CARP (CTENOPHARYNGODON IDELLUS) SURIMI DURING FROZEN STORAGE." Journal of Food Processing and Preservation 34(4), 2010, 715-727.

[28] V. D. Pawar, B. D. Mule and G. M. Machewad, "EFFECT OF MARINATION WITH GINGER RHIZOME EXTRACT ON PROPERTIES OF RAW AND COOKED CHEVON." Journal of Muscle Foods 18(4), 2007, 349-369.

[29] Jonsson, Sigurgisladottir, Hafsteinsson and Kristbergsson,"Textural properties of raw Atlantic salmon (Salmo salar) fillets measured by different methods in comparison to expressible moisture." Aquaculture Nutrition 7(2), 2001, 81-89.

[30] A. M. B. Rørå, C. Regost and J. Lampe,"Liquid holding capacity, texture and fatty acid profile of smoked fillets of Atlantic salmon fed diets containing fish oil or soybean oil." Food Research International 36(3), 2003, 231-239.

[31] C. Shi, J. Cui, Y. Luo and Z. Zhou,"Effect of lightly salt and sucrose on rigor mortis changes in silver carp (Hypophthalmichthys molitrix) stored at $4{ }^{\circ} \mathrm{C} . "$ International Journal of Food Science \& Technology, 2013.

[32] Z. Sikorski and A. Kołakowska, "Changes in Proteins in Frozen Stored Fish. Seafood Proteins", Springer US, 1995, 99-112.

[33] L. Taskaya, Y.C. Chen, S. Beamer and J. Jaczynski, "Texture and colour properties of proteins recovered from whole gutted silver carp (Hypophthalmichthys molitrix) using isoelectric solubilisation/precipitation." Journal of the Science of Food and Agriculture 89(2), 2009, 349-358.

[34] B. Tokur, S. Ozkütük, E. Atici, G. Ozyurt and C. E. Ozyurt,"Chemical and sensory quality changes of fish fingers, made from mirror carp (Cyprinus carpio L., 1758), during frozen storage $\left(-18^{\circ} \mathrm{C}\right)$." Food Chemistry $99(2)$, 2006, 335-341.

[35] L. L. Tsai, N. J. Yen and R. G. R. Chou,"Changes in Muscovy duck breast muscle marinated with ginger extract." Food Chemistry 130(2), 2012, 316-320.

[36] G. Xiong, W. Cheng, L. Ye, X. Du, M. Zhou, R. Lin, S. Geng, M. Chen, H. Corke and Y. Cai,"Effects of konjac glucomannan on physicochemical properties of myofibrillar protein and surimi gels from grass carp (Ctenopharyngodon idella)." Food Chemistry 116(2), 2009, 413-418.

[37] M.C. Yin and W.S. Cheng, "Antioxidant and antimicrobial effects of four garlic-derived organosulfur compounds in ground beef." Meat Science 63(1), 2003, 23-28.

[38] A. Zhou, S. Benjakul,K. Pan, J. Gong and X. Liu,"Cryoprotective effects of trehalose and sodium lactate on tilapia (Sarotherodon nilotica) surimi during frozen storage." Food Chemistry 96(1), 2006,96-103. 
[39] H. TANABE, M. YOSHIDA and N. TOMITA, "Comparison of the antioxidant activities of 22 commonly used culinary herbs and spices on the lipid oxidation of pork meat."
Animal Science Journal 73(5), 2002, 389-393. 